\title{
A Study on Distribution and Characteristics of Radon Concentration in Metro Line 1 in Busan
}

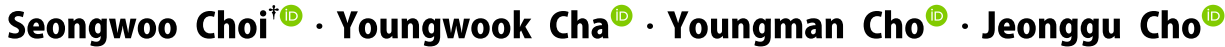

Busan Metropolitan City Institute of Health \& Environment, Korea

(Received October 18, 2019; Revised December 24, 2019; Accepted January 2, 2020)

Objective: Adverse health effects of Radon with a particular focus on indoor environment has been outlined. Most of the metro stations and platforms are situated under the ground where relatively enhanced concentration of radon has been observed.

Method: On-line measurements of indoor Radon have been made in Metro Line 1 in Busan using RAD-7.

Results and Discussion: The average concentration of Radon was $8.9 \mathrm{~Bq} / \mathrm{m}^{3}(\mathrm{n}=40)$. In general, a positive relation was shown between the level of radon and the depth of station. Slightly enhanced radon concentrations were observed between 0 a.m. $\sim 5$ a.m. when the station is closed under the non-operation of ventilation system. Interestingly, the negative relation was seen between the radon revel and temperature.

Conclusions: Relatively low levels of indoor radon has been observed in Metro Line 1 in Busan, which may be associated with geographical location of non-granite regions.

Key Words: Radon, Subway, Underground Station, Platform, Concourse 


\title{
부산도시철도 1호선의 라돈농도 분포 및 특성에 관한 연구
}

\author{
최성우 ${ }^{\oplus} \cdot$ 차영욱 $^{\circledR} \cdot$ 조영만 $^{\oplus} \cdot$ 조정구 ${ }^{\oplus}$ \\ 부산광역시 보건환경연구원
}

목적: 실내 라돈은 제한된 공간에서 인체 건강에 심각한 악영향을 미친다. 도시철도 역사 대부분은 지하공간에 위치하고, 지하철과 같은 지하공간은 라돈성분이 증가하는 것으로 알려져 있다.

방법 : RAD-7을 이용하여 지하철 1호선에서 실내공기의 라돈농도를 연속측정하였다.

결과 및 토의: 측정 결과 40 개 지하철역에 측정한 평균 라돈농도는 $8.9 \mathrm{~Bq} / \mathrm{m}^{3}$ 이었으며, 심도가 깊은 지하역사에서 상대적으로 높은 라돈농도가 측정되었다. 지하철 운행이 중단되고 환기시설이 가동되지 않는 0 시에서 5 시에 라돈 농도가 증가하였고, 승강장과 대합실에서 측정한 평균 라돈농도는 온도가 낮을수록 높은 것으로 나타났다.

결론: 부산 지하철 1 호선은 비화강암 지역에 위치하여 상대적으로 낮은 라돈농도가 나타났다.

주제어 : 라돈, 지하철, 지하역사, 승강장, 대합실

\section{1. 서 론}

부산도시철도는 1985년 7월 개통이래 2018년 기준으로 연 간 약 3 억3천6백만명이 이용하는 대표적인 대중교통수단이 다. ${ }^{1)}$ 하지만 도시철도 역사의 대부분은 지하공간에 위치하 고 자연환기가 어려우므로 다수의 이용객이 밀집하게 되면 다양한 실내공기 오염에 노출될 우려가 있다. 지하역사에 발 생하는 오염물질은 미세먼지, 이산화탄소, 라돈, 석면, 휘발 성유기화합물 등이 있으며, 이들의 대부분은 인위적으로 생 성되지만, 라돈 $\left.{ }^{222} \mathrm{Rn}\right)$ 은 다른 실내오염물질과 달리 자연 발 생적인 방사성 물질이기 때문에 관리상 어려움이 수반된다.

라돈은 지각의 암석이나 토양 또는 건축자재 등에 존재하 는 우라늄 $\left({ }^{238} \mathrm{U}\right)$ 과 토륨 $\left({ }^{232} \mathrm{Th}\right)$ 이 몇 차례 붕괴를 거치는 과 정에서 생성되는 무색, 무취, 무미의 기체로 지구상 어디에 서나 존재하는 자연방사성 물질이다. ${ }^{2}$ 다른 물질과 화학적 으로 반응을 하지 않는 불활성기체이나 방사선을 내는 성질 이 있으므로 매우 불안정하며 물질표면에 흡착성이 강하고 공기밀도보다 약 8 배 정도 크다. 라돈 기체와 그 붕괴생성 물인 입자상태의 라돈자손은 호흡을 통해 몸속으로 들어 와 폐포나 기관지에 잘 달라붙어 손상을 일으킨다. 세계보건 기구(WHO) 산하기관인 국제암연구소(IARC: International Agency for Research on Cancer)는 라돈과 라돈자손을 1군 발암물질로 분류하였다. 또한, $\mathrm{WHO}$ 에서는 전 세계적으로 발 생하는 폐암의 3 14\%가 라돈에 노출되어 발생한 것으로 보
고, 라돈을 흡연에 이은 두 번째 원인물질로 지정하고 있다. ${ }^{3)}$ 대부분의 실내공간에서 검출되는 라돈은 토양가스의 유 입에 의한 것이며 건축재료 및 지하수 사용도 원인이 된 다. ${ }^{24)}$ 토양 및 건축자재의 함수율 등 구조적 요인과 온도, 압력, 습도 등 기상학적인 요인도 실내공간의 라돈분포에 영향을 미치며, 환기정도 등 생활습관도 실내의 라돈농도 와 밀접한 관계가 있는 것으로 알려져 있다. ${ }^{5,6)}$

우리나라는 1989년에 “지하공간환경기준치설정”으로 라돈 의 권고기준을 $4 \mathrm{pCi} / \mathrm{L}$ 로 정하였고, 1996년 “지하생활공간 공기질관리법”에서는 라돈을 오염물질로 규정하였으나 자연 방사능 물질이라서 기준을 설정하지 않았다. 그 후 2003년 “다중이용시설 등의 실내공기질관리법”의 제정으로 라돈의 권고기준을 $4 \mathrm{pCi} / \mathrm{L}$ 로 하였으며, 2010년도에 법이 개정되면 서 $148 \mathrm{~Bq} / \mathrm{m}^{3}$ 을 권고기준으로 하고 있다. 이는 미국의 Action Level과 동일한 수준이다. ${ }^{7)}$

현재 국내에서 적용하고 있는 도시철도 지하역사에서의 라돈 저감방법은 지하수 표면으로부터 방출되는 라돈이 공 기 중으로 방출되는 것을 억제하기 위해 승강장을 포함한 승강장 근처의 집수로 및 집수정에 덮개를 설치하는 방법 과 승강장으로 방출된 라돈의 농도를 희석시키기 위해 환 기횟수를 증가시키는 방법 등을 사용하고 있으나, 열차풍 에 의해 터널 내부의 고농도 라돈을 함유한 공기가 계속해 서 승강장으로 유입되는 한계가 있다. ${ }^{8)}$ 이러한 문제점을 해결하기 위해 국내 라돈관련 연구는 간헐적으로 수행되었 
지만 종합적이고 체계화된 학술적 연구는 부족한 실정이 며, 특히 다수인이 이용하는 지하역사 내 라돈에 대한 연구 는 서울지하철을 중심으로만 진행되었을 뿐 부산지하철 등 지방 도시철도에 대한 연구는 거의 전무한 실정이다. ${ }^{9-12)}$ 따 라서, 본 연구는 부산도시철도 이용객의 $50 \%$ 이상을 수송 하는 1 호선 40 개 역사를 대상으로 승강장과 대합실 라돈농 도의 시간적 변화를 조사하여 지하철역 이용 시민 및 역내 작업자의 라돈으로부터 받을 수 있는 위해를 줄이고 공기 질 관리 및 유지에 필요한 기초자료로 활용하고자 한다.

\section{2. 실험방법}

본 연구에서는 부산도시철도 1 호선 각 역사 선정지점별로 3 월부터 7월까지 단기라돈을 측정하였다. 시료채취는 실내 공기질 공정시험기준 ES 02901.1a에 따라 실시하는 것을 원 칙으로 하였으며, 시료채취 당시의 온도·기압·풍속 등 물리 적 환경인자에 관한 정보를 기록하였다. 시료채취 지점은 승강장과 대합실에 연속식 측정기인 RAD-7 (DURRIDGE Company, USA)을 사용하여 1시간 간격으로 11:00부터 이틀 후 11:00까지 총 48시간동안 연속적으로 측정하였다. 연속

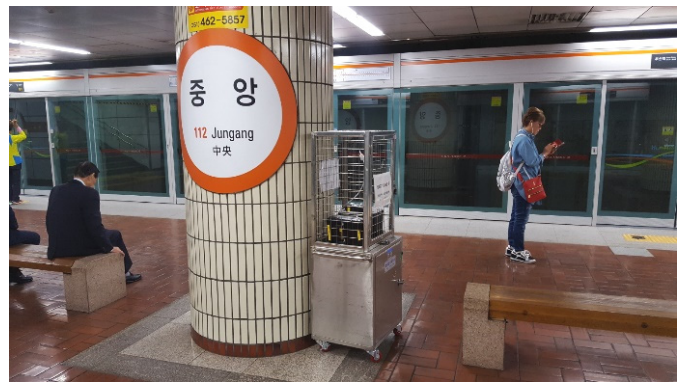

Platform
식 라돈농도 측정기의 원리는 라돈원자가 붕괴할 때 5.49 $\mathrm{MeV}$ 의 에너지를 가진 알파입자가 방출되는데, 이 에너지를 반도체(실리콘)을 이용하여 전기적 부호로 전환시켜 스펙트 럼 또는 문자로 표시한다.

부산도시철도 1 호선 40 개역은 32 개의 지하역사와 6 개의 고가역사 및 2 개의 지상역사로 이루어져 있으며, 시료의 채취는 일변화 및 지하역사 깊이에 대한 영향을 측정하 기 위하여 각 역사의 승강장과 대합실에서 통행량이 많은 지점을 선정하여 라돈농도를 연속적으로 모니터링하였다. Fig. 1 과 같이 승강장은 구간 내 정중앙지점, 대합실은 고 객서비스센터 앞을 선정하였으며, 측정지점별 역사심도, 평균온도, 측정일자는 Table 1과 같다.

\section{3. 결과 및 고찰}

\section{1. 도시철도 1 호선 역사의 라돈농도}

부산도시철도 1 호선 40 개 역사를 대상으로 1 시간 간격으 로 48 시간 동안 측정한 라돈농도는 Table 2와 같으며, 지하 역사, 지상역사 및 승강장과 대합실의 산술평균값을 비교 하여 Fig. 2와 Fig.3에 나타내었다.

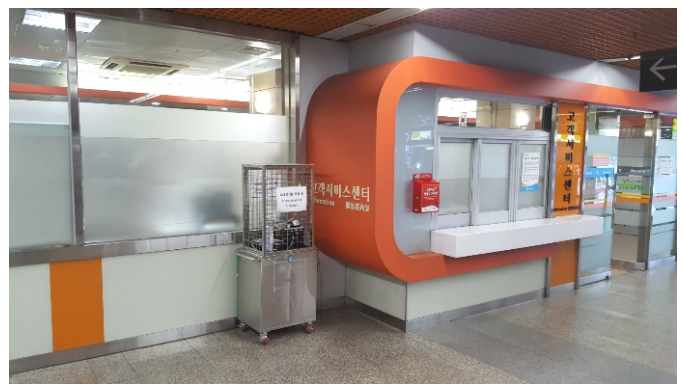

Concourse

Fig. 1. Photograph of sampling sites.

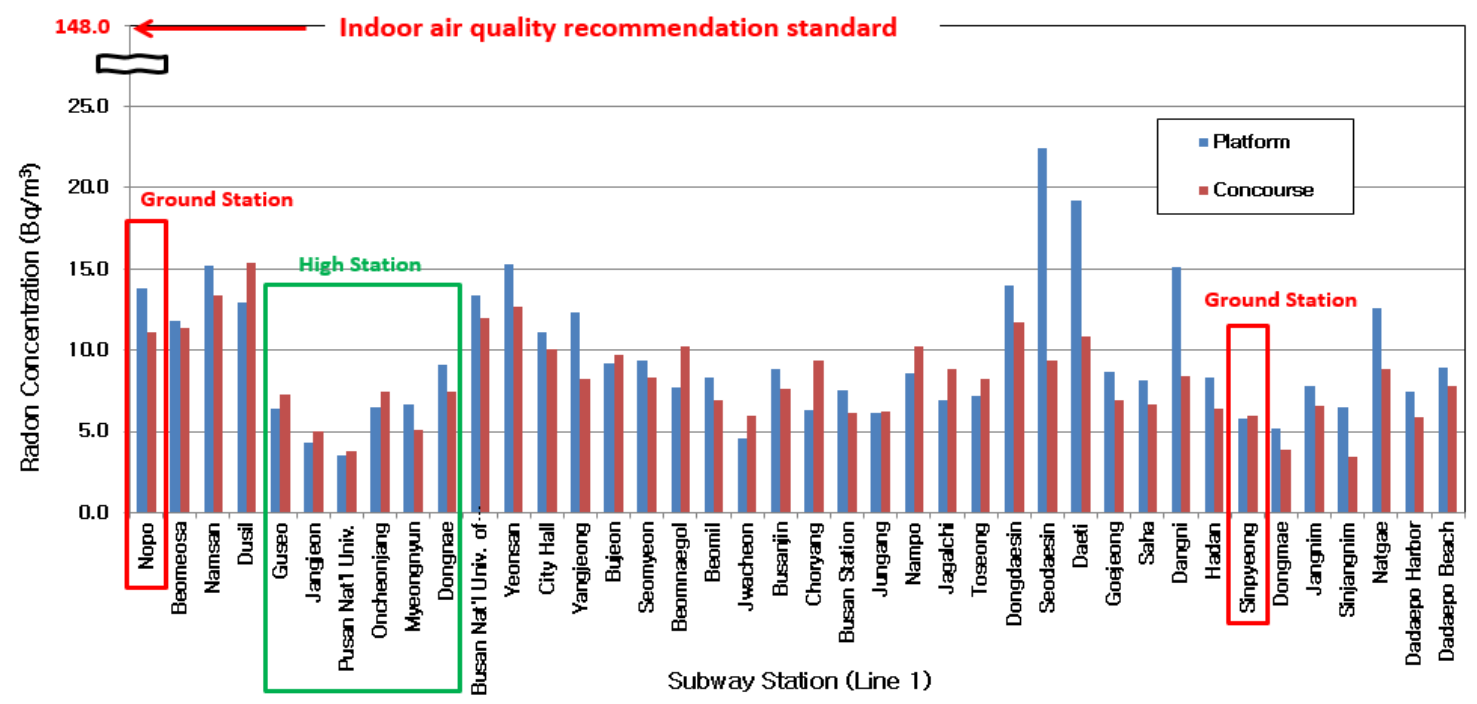

Fig. 2. Distributions of radon mean concentration at each site of subway stations. 
Table 1. Sampling sites for this study in Busan subway line 1.

\begin{tabular}{|c|c|c|c|c|c|c|}
\hline \multirow{2}{*}{ Site } & \multicolumn{2}{|c|}{ Station Depth (m) } & \multicolumn{2}{|c|}{ Temperature $\left({ }^{\circ} \mathrm{C}\right)$} & \multirow{2}{*}{ Date } & \multirow{2}{*}{ Remarks } \\
\hline & Platform & Concourse & Platform & Concourse & & \\
\hline Nopo & - & - & 15.8 & 15.5 & $3 / 15-3 / 17$ & Ground station \\
\hline Beomeosa & 14.27 & 9.97 & 14.9 & 17.3 & $3 / 8-3 / 10$ & \\
\hline Namsan & 10.02 & 5.67 & 15.3 & 16.2 & $3 / 10-3 / 12$ & \\
\hline Dusil & 13.35 & 9 & 15.8 & 15.7 & $3 / 13-3 / 15$ & \\
\hline Guseo & - & - & 28.2 & 28.4 & $7 / 5-77$ & High station \\
\hline Jangjeon & - & - & 28.8 & 28.8 & $7 / 3-7 / 5$ & High station \\
\hline Pusan Nat'I Univ. & - & - & 29.2 & 28.5 & $6 / 30-7 / 2$ & High station \\
\hline Oncheonjang & - & - & 28.9 & 28.2 & $6 / 28-6 / 30$ & High station \\
\hline Myeongnyun & - & - & 25.9 & 26.3 & $6 / 26-6 / 28$ & High station \\
\hline Dongnae & - & - & 27.7 & 27 & $6 / 22-6 / 24$ & High station \\
\hline Busan Nat'I Univ. of edu. & 6.12 & 6.12 & 16.6 & 17.1 & $3 / 17-3 / 19$ & \\
\hline Yeonsan & 11.96 & 7.66 & 18.9 & 18.5 & $3 / 20-3 / 22$ & \\
\hline City Hall & 11.1 & 6.8 & 17.4 & 17.8 & $3 / 22-3 / 24$ & \\
\hline Yangjeong & 12.11 & 7.81 & 20.1 & 17.6 & $3 / 24-3 / 26$ & \\
\hline Bujeon & 10.37 & 6.07 & 16.5 & 17.4 & $3 / 27-3 / 29$ & \\
\hline Seomyeon & 13.03 & 8.61 & 17.5 & 18.4 & $3 / 29-3 / 31$ & \\
\hline Beomnaegol & 12.3 & 7.95 & 15.9 & 17.4 & $3 / 31-4 / 2$ & \\
\hline Beomil & 11.83 & 7.53 & 20.2 & 20.7 & $4 / 5-4 / 7$ & \\
\hline Jwacheon & 12.99 & 8.69 & 18.4 & 18.6 & $4 / 26-4 / 28$ & \\
\hline Busanjin & 12.08 & 7.78 & 23.7 & 22.1 & $4 / 28-4 / 30$ & \\
\hline Choryang & 11.94 & 7.64 & 22.7 & 22.2 & $5 / 1-5 / 3$ & \\
\hline Busan Station & 11.71 & 7.41 & 23.9 & 23.8 & $5 / 4-5 / 6$ & \\
\hline Jungang & 12.82 & 8.47 & 23.8 & 24.2 & $5 / 8-5 / 10$ & \\
\hline Nampo & 14.28 & 9.9 & 24.7 & 24.9 & $5 / 10-5 / 12$ & \\
\hline Jagalchi & 13.28 & 8.98 & 23.5 & 23.9 & $5 / 12-514$ & \\
\hline Toseong & 12.18 & 7.8 & 21.4 & 21.8 & $5 / 15-5 / 17$ & \\
\hline Dongdaesin & 12.58 & 8.2 & 22.7 & 22.5 & $5 / 17-5 / 19$ & \\
\hline Seodaesin & 24.3 & 10.2 & 25.4 & 24.9 & $5 / 19-5 / 21$ & \\
\hline Daeti & 26.14 & 7.08 & 24.2 & 24.3 & $5 / 22-5 / 24$ & \\
\hline Goejeong & 15.09 & 10.71 & 23.8 & 24.3 & $5 / 24-5 / 26$ & \\
\hline Saha & 12.45 & 8.15 & 23.4 & 22.7 & $5 / 26-5 / 28$ & \\
\hline Dangni & 12.71 & 8.41 & 24.4 & 24.5 & $5 / 29-5 / 31$ & \\
\hline Hadan & 11.68 & 7.3 & 24.9 & 24.8 & $5 / 31-6 / 2$ & \\
\hline Sinpyeong & - & - & 23.6 & 23.7 & $6 / 2-6 / 4$ & Ground station \\
\hline Dongmae & 15.0 & 10.0 & 23.9 & 23.7 & $6 / 5-67$ & \\
\hline Jangnim & 19.0 & 14.0 & 25.6 & 25.6 & $6 / 9-6 / 11$ & \\
\hline Sinjangnim & 19.5 & 14.5 & 23.9 & 23.2 & $6 / 12-6 / 14$ & \\
\hline Natgae & 23.5 & 12.5 & 24.9 & 24.7 & $6 / 14-6 / 16$ & \\
\hline Dadaepo Harbor & 17.5 & 12.0 & 26.2 & 25.5 & $6 / 16-6 / 18$ & \\
\hline Dadaepo Beach & 15.5 & 10.5 & 24.5 & 24.6 & $6 / 19-6 / 21$ & \\
\hline
\end{tabular}

부산도시철도 40 개 역사에서 측정한 1 호선 평균 라돈농도 는 $8.9 \mathrm{~Bq} / \mathrm{m}^{3}$ 으로 실내공기질 권고기준 $148 \mathrm{~Bq} / \mathrm{m}^{3}$ 보다 매우 낮게 조사되었다. 40 개 역사의 대합실 평균 라돈농도는 8.3 $\mathrm{Bq} / \mathrm{m}^{3}$ 이었으며, 대합실보다 상대적으로 깊은 곳에 위치한
승강장의 평균 라돈농도는 $9.6 \mathrm{~Bq} / \mathrm{m}^{3}$ 으로 조사되었다. 서울 지하철의 경우 승강장 안전문(PSD : Platform Screen Door) 설치 전엔 Lee 등의 연구에서 승강장 평균 라돈농도가 61.8 $\mathrm{Bq} / \mathrm{m}^{3}$, 대합실은 $38.2 \mathrm{~Bq} / \mathrm{m}^{3}$ 으로 조사되었고, ${ }^{13)} \mathrm{PSD}$ 설치 
Table 2. Radon concentrations $\left(\mathrm{Bq} / \mathrm{m}^{3}\right)$ according to each site of subway stations line 1 .

\begin{tabular}{|c|c|c|c|c|c|c|}
\hline \multirow{2}{*}{ Site } & \multicolumn{3}{|c|}{ Platform } & \multicolumn{3}{|c|}{ Concourse } \\
\hline & $\min$ & $\max$ & mean & $\min$ & $\max$ & mean \\
\hline Nopo & 2.8 & 30.5 & 13.8 & 5.6 & 22.3 & 11.1 \\
\hline Beomeosa & 1.4 & 25.1 & 11.8 & 2.9 & 20.6 & 11.4 \\
\hline Namsan & 5.6 & 29.3 & 15.2 & 1.4 & 26.1 & 13.4 \\
\hline Dusil & 0.0 & 32.8 & 12.9 & 5.5 & 31.6 & 15.4 \\
\hline Guseo & 0.0 & 19.5 & 6.4 & 0.0 & 22.0 & 7.3 \\
\hline Jangjeon & 0.0 & 20.8 & 4.3 & 0.0 & 13.7 & 5.0 \\
\hline Pusan Nat'I Univ. & 0.0 & 12.6 & 3.5 & 0.0 & 11.5 & 3.8 \\
\hline Oncheonjang & 0.0 & 19.5 & 6.5 & 0.0 & 19.2 & 7.4 \\
\hline Myeongnyun & 0.0 & 19.6 & 6.7 & 0.0 & 20.5 & 5.1 \\
\hline Dongnae & 0.0 & 29.3 & 9.1 & 0.0 & 22.0 & 7.4 \\
\hline Busan Nat'I Univ. of edu. & 2.8 & 27.9 & 13.4 & 2.8 & 28.9 & 12.0 \\
\hline Yeonsan & 5.6 & 33.5 & 15.3 & 0.0 & 28.9 & 12.7 \\
\hline City Hall & 1.4 & 25.1 & 11.1 & 2.7 & 22.0 & 10.1 \\
\hline Yangjeong & 1.4 & 23.7 & 12.3 & 0.0 & 27.5 & 8.2 \\
\hline Bujeon & 2.8 & 19.5 & 9.2 & 1.4 & 20.6 & 9.7 \\
\hline Seomyeon & 1.4 & 23.7 & 9.4 & 0.0 & 17.9 & 8.3 \\
\hline Beomnaegol & 0.0 & 18.1 & 7.7 & 1.4 & 20.6 & 10.2 \\
\hline Beomil & 0.0 & 21.0 & 8.3 & 0.0 & 17.9 & 6.9 \\
\hline Jwacheon & 0.0 & 11.2 & 4.6 & 0.0 & 12.4 & 6.0 \\
\hline Busanjin & 0.0 & 16.7 & 8.8 & 0.0 & 19.2 & 7.6 \\
\hline Choryang & 0.0 & 13.9 & 6.3 & 0.0 & 24.7 & 9.4 \\
\hline Busan Station & 1.4 & 18.1 & 7.5 & 1.4 & 15.1 & 6.1 \\
\hline Jungang & 0.0 & 18.1 & 6.2 & 0.0 & 16.5 & 6.2 \\
\hline Nampo & 1.4 & 21.0 & 8.6 & 1.4 & 24.7 & 10.2 \\
\hline Jagalchi & 0.0 & 18.1 & 6.9 & 1.4 & 16.5 & 8.8 \\
\hline Toseong & 2.8 & 18.1 & 7.2 & 2.9 & 14.4 & 8.2 \\
\hline Dongdaesin & 1.4 & 44.7 & 14.0 & 0.0 & 23.4 & 11.7 \\
\hline Seodaesin & 7.0 & 40.5 & 22.4 & 0.0 & 22.0 & 9.4 \\
\hline Daeti & 5.6 & 37.9 & 19.2 & 0.0 & 38.2 & 10.8 \\
\hline Goejeong & 0.0 & 20.9 & 8.7 & 0.0 & 15.1 & 6.9 \\
\hline Saha & 0.0 & 21.0 & 8.1 & 0.0 & 16.5 & 6.7 \\
\hline Dangni & 4.2 & 29.1 & 15.1 & 1.4 & 19.5 & 8.4 \\
\hline Hadan & 1.4 & 16.8 & 8.3 & 0.0 & 12.4 & 6.4 \\
\hline Sinpyeong & 0.0 & 22.3 & 5.8 & 0.0 & 17.9 & 6.0 \\
\hline Dongmae & 0.0 & 13.8 & 5.2 & 0.0 & 10.9 & 3.9 \\
\hline Jangnim & 0.0 & 20.8 & 7.8 & 0.0 & 19.2 & 6.6 \\
\hline Sinjangnim & 0.0 & 16.8 & 6.5 & 0.0 & 11.0 & 3.4 \\
\hline Natgae & 0.0 & 36.3 & 12.6 & 0.0 & 45.0 & 8.8 \\
\hline Dadaepo Harbor & 0.0 & 18.1 & 7.4 & 0.0 & 16.5 & 5.9 \\
\hline Dadaepo Beach & 2.8 & 23.7 & 8.9 & 0.0 & 31.6 & 7.8 \\
\hline
\end{tabular}

후엔 Jeon 등의 연구에서 승강장 평균 라돈농도 $54 \mathrm{~Bq} / \mathrm{m}^{3}$, 대합실 평균 라돈농도 $34 \mathrm{~Bq} / \mathrm{m}^{3}$ 으로 보고되었다. ${ }^{14)}$ 부산지 하철은 현재 전 역사에 PSD가 설치되어 있으므로 PSD 설치 전과 후의 변화값은 알 수 없으나 Lee와 Jeon 등의 서울지하 철 평균농도와 비교하더라도 PSD가 설치된 부산도시철도 1 호선 평균 라돈농도는 상대적으로 낮은 농도임을 알 수 있
었고, 승강장이 대합실보다 높은 농도를 보이는 경향은 유 사하게 나타났다.

\section{2. 지하역사 심도에 따른 라돈농도}

부산도시철도 1 호선 32 개 지하역사와 8 개 지상역사(지상 2 개, 고가 6 개)의 승강장과 대합실의 라돈농도를 측정한 


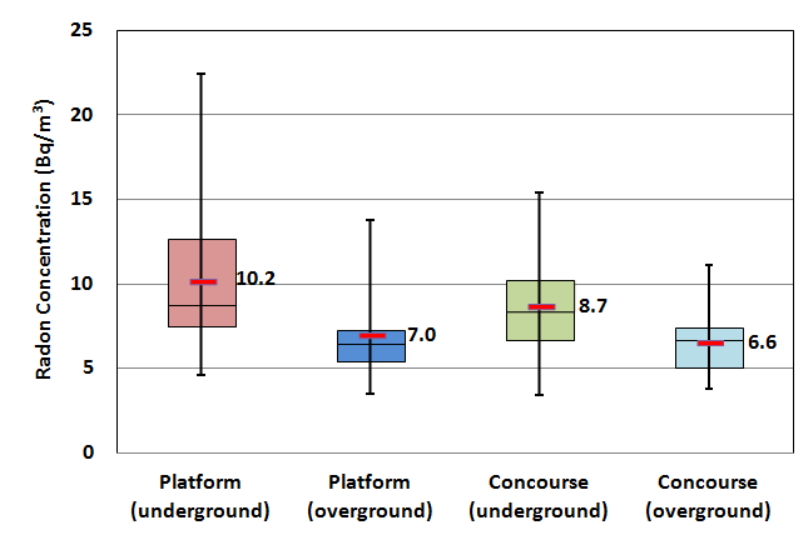

Fig. 3. Boxplot of radon concentration at each site of subway stations.

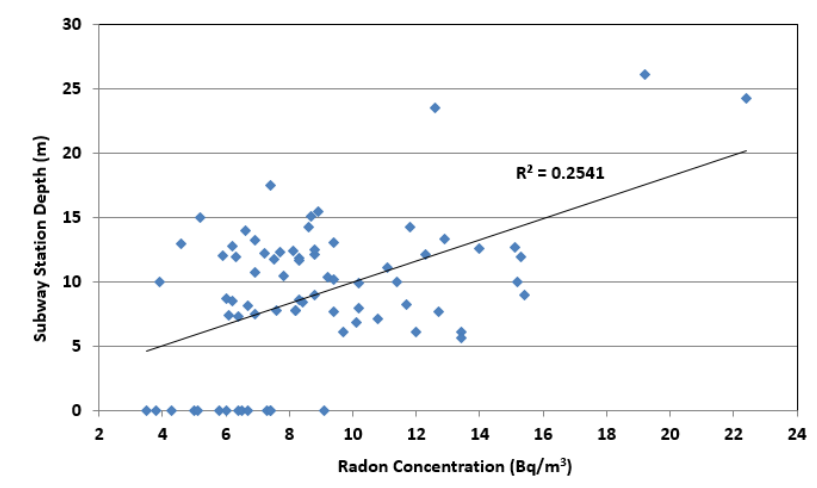

Fig. 4. Radon concentration and relations between subway stations depth.

결과 지하역사 라돈농도는 승강장이 $4.6 ~ 22.4 \mathrm{~Bq} / \mathrm{m}^{3}$ (평균 $10.2 \mathrm{~Bq} / \mathrm{m}^{3}$ ), 대합실이 $3.4 \sim 15.4 \mathrm{~Bq} / \mathrm{m}^{3}$ (평균 $8.7 \mathrm{~Bq} / \mathrm{m}^{3}$ ), 지 상역사 라돈농도는 승강장이 $3.5 \sim 13.8 \mathrm{~Bq} / \mathrm{m}^{3}$ (평균 $7.0 \mathrm{~Bq} / \mathrm{m}^{3}$ ), 대합실이 $3.8 \sim 11.1 \mathrm{~Bq} / \mathrm{m}^{3}$ (평균 $6.6 \mathrm{~Bq} / \mathrm{m}^{3}$ )으로 지상역사보 다 지하역사의 라돈농도가 높게 나타났으며, 승강장이 대합 실보다 높게 나타나 라돈농도는 심도에 의한 영향이 높은 것으로 판단되었다. 또한 40 개 역사 중 서대신동 승강장이 48 시간 평균 $22.4 \mathrm{~Bq} / \mathrm{m}^{3}$ 으로 가장 높게 나타났으며, 승강장 심도가 깊은 서대신동, 대티, 낫개역이 상대적으로 높은 값 으로 측정되었다. 시간당 최대값은 낫개역 대합실이 45.0 $\mathrm{Bq} / \mathrm{m}^{3}$, 동대신동 승강장이 $44.7 \mathrm{~Bq} / \mathrm{m}^{3}$ 으로 나타났으나, 실 내공기질 라돈 권고기준 $148 \mathrm{~Bq} / \mathrm{m}^{3}$ 의 $30 \%$ 정도로 안전함 을 알 수 있었다.

Fig. 4는 라돈농도와 역사심도와의 상관관계가 있음을 나 타내고 있다.

\section{3. 시간변화에 따른 라돈농도}

라돈농도의 시간적 변화를 측정하기 위하여 RAD-7 연속 식 측정기로 오전 11시부터 이틀 후 11시까지 48시간동안 측정한 40개 역사 시간별 평균 라돈농도는 Fig.5와 같다. 측정기간 동안 지하철 운행이 중단되고 환기시설이 가

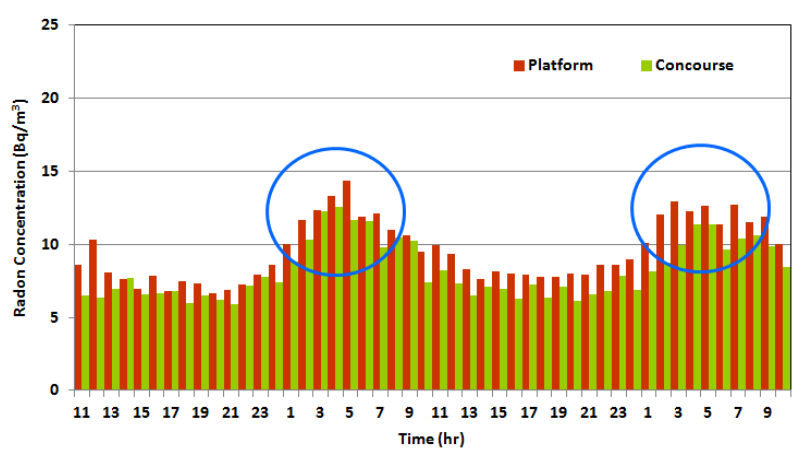

Fig. 5. Daily variation of radon mean concentration at subway stations.

동되지 않는 0 시에서 5 시에 라돈농도가 증가하는 것으로 나타났다. 라돈농도 최대값의 경우 승강장은 5시에 14.3 $\mathrm{Bq} / \mathrm{m}^{3}$, 대합실은 4 시에 $12.5 \mathrm{~Bq} / \mathrm{m}^{3}$ 으로 나타났으며, 최소값 의 경우 승강장은 20 시에 $6.6 \mathrm{~Bq} / \mathrm{m}^{3}$, 대합실은 21 시에 5.9 $\mathrm{Bq} / \mathrm{m}^{3}$ 으로 조사되었다. 이는 Jeon 등 ${ }^{11)}$ 과 $\mathrm{Yu}$ 등의 연구 ${ }^{15)}$ 에 서와 유사한 경향을 보이는 것으로 승강장의 환기가동 시 간에 따른 라돈농도의 변화폭이 매우 큰 것을 알 수 있다. 부산도시철도의 경우 5시부터 24시까지 역사공기질에 따 라 가동속도를 조절하여 연속적으로 환기시스템을 가동하 고 있으나, 출근시간대보다 퇴근시간대 라돈농도는 급격한 감소가 나타났다. 이는 퇴근시간대 환기량 증가에 의한 것 으로 지하역사 등 실내공간에서 환기량 증가는 라돈농도를 저감시킬 수 있는 매운 중요한 요인임을 확인할 수 있다. 또한 열차가 운행하기 시작하는 6시 경에 라돈의 일시적인 감소가 일어났는데, 이는 Jeon 등의 연구에서와 마찬가지 로 밤사이 공기의 큰 유동이 없다가 열차운행으로 발생하 는 열차풍에 의한 것으로 추정된다. ${ }^{11)}$ 열차가 운행되는 동 안은 열차풍의 환기효과는 어느 정도 지속되는 것으로 판 단된다.

1 시간 간격으로 48 시간 연속측정한 라돈농도 중 최고 상 승하는 시간대를 알아보고자 Fig.6에 48시간 중 최고 라돈 농도가 측정된 동대신동역과 낫개역 등 3 개 역사의 측정시 간을 나타내었다. 평균 라돈농도와 마찬가지로 시간당 최고 라돈농도도 환기시설이 가동되지 않는 0 시에서 5 시에 나타 났고, 이 측정값은 실내공기질 라돈 권고기준 $148 \mathrm{~Bq} / \mathrm{m}^{3}$ 보 다는 낮은 값임을 알 수 있었다.

\section{4. 온도변화에 따른 라돈농도}

Fig.7에는 부산도시철도 1호선 40개 역사의 승강장과 대 합실에서 3 월부터 7 월까지 측정한 온도와 라돈농도와의 관 계를 나타내었다.

상관계수의 값은 높지 않지만, 3 월부터 7 월까지 조사한 승강장과 대합실내 온도는 $14.9 \sim 29.2^{\circ} \mathrm{C}$ 로 온도가 낮을수록 평균 라돈농도는 높은 것으로 조사되었다. 일반적으로 지 하철역 승강장의 여름철 실내환경은 매우 무더우므로 온도 


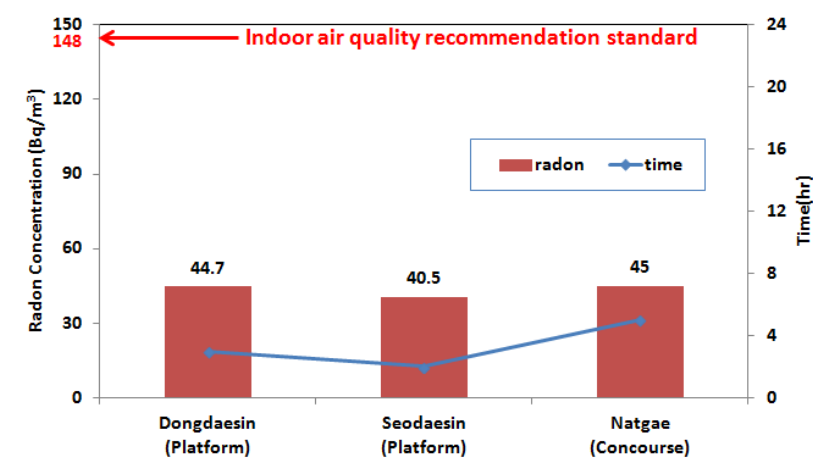

Fig. 6. Comparisons of radon concentration and time at subway stations measured high level radon.

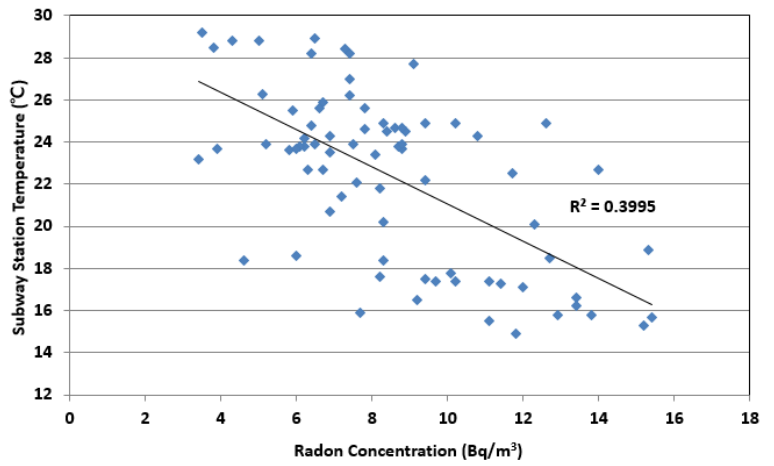

Fig. 7. Radon concentration and relations between subway station temperature.

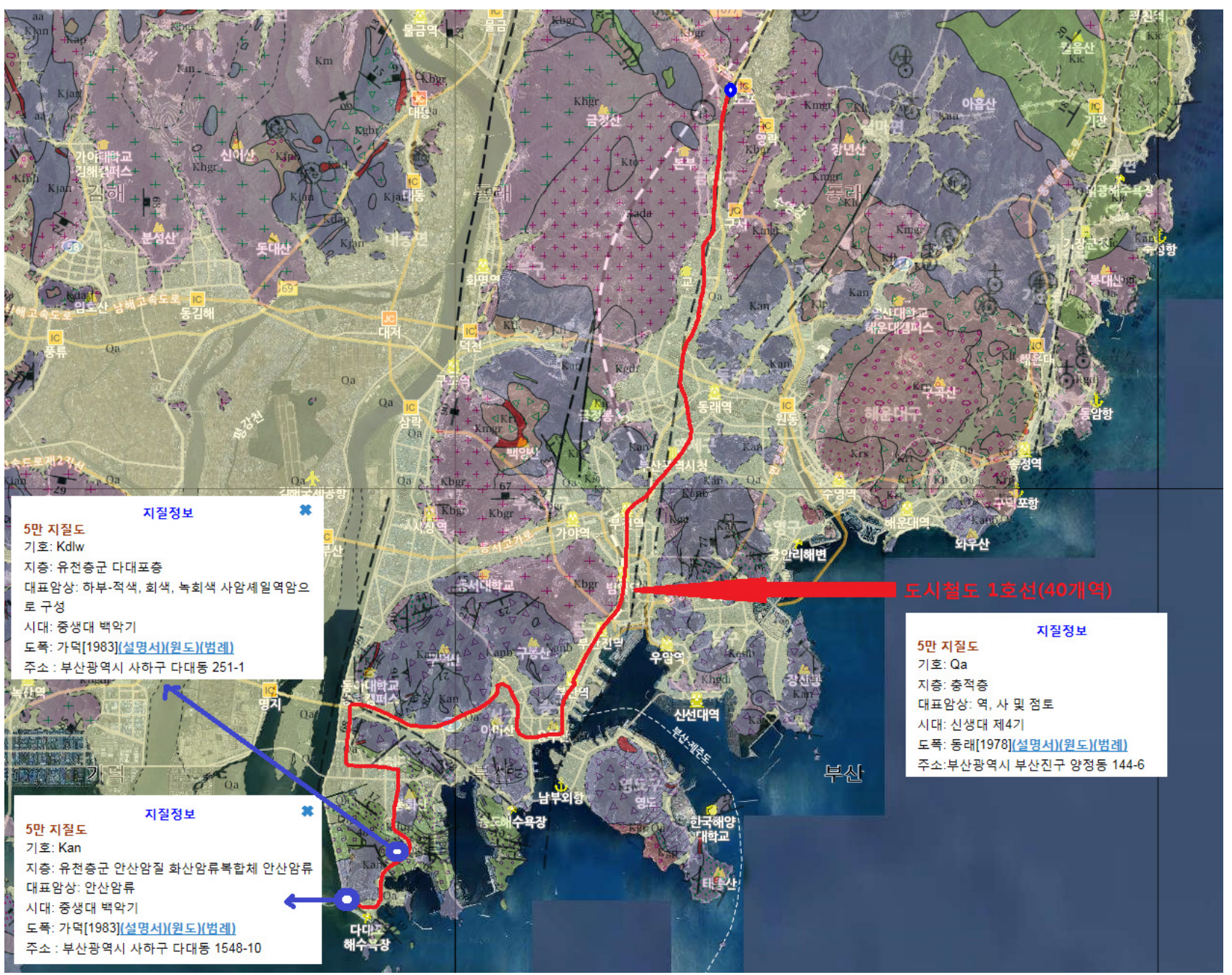

Fig. 8. Distribution of geologic map in Busan subway stations line 1.

센서에 의해 적정한 환기량을 조절하게 된다. 이에 따라 효 율적인 냉방시설 가동을 위해 환기시스템의 가동비율이 증 가하므로 $\mathrm{Li}$ 등의 연구결과 ${ }^{16)}$ 와 유사하게 여름철이 낮은 농도값을 보였다. 이러한 결과는 Miles 등에 의해서 조사된 일반적인 실내의 계절별 변화 양상과 유사한 형태이다. ${ }^{17)}$ 일반적으로 겨울철에는 환기시스템의 가동시간이 줄어들
어 실내에 있던 라돈이 바깥으로 빠져나기 어렵게 만들어 실내 라돈농도가 높아지는 것으로 알려져 있다. ${ }^{18)}$

\section{5. 기반암석에 따른 라돈농도}

라돈은 화강암·변성암과 같은 암석, 토양 그리고 우라늄 이나 라듐을 함유한 건축자재에서 발생한다. 우리나라에서 
도 화강암-편마암 지질대나 옥천단층 지대에 있는 지역에 서 라돈농도가 높게 나타나는 것으로 조사되고 있다. 따라 서, 부산도시철도 1 호선 40 개 역사가 위치한 기반암석이 라돈농도에 미치는 영향을 파악하기 위하여 한국지질자원 연구원 지리정보시스템을 활용하여 Fig. 8에 나타내었다.

서울시의 지질은 편마암과 선캄브리아기 편마암 밑의 마 그마가 뚫고 들어온 뒤 오랜 세월동안 지각변동과 침식을 거쳐 드러난 화강암 구조로 이루어져 있으며, 이러한 화강암 을 기반으로 하는 지하철 역사를 많이 가지고 있어 고농도 의 라돈분포가 나타난다. ${ }^{10)}$ 부산지역 구성암류의 지질시대 는 크게 백악기, 제 3 기, 제 4 기로 구분되고, 제 4 기 $47.02 \%$, 백 악기 $41.0 \%$ 및 제 3 기 $6.73 \%$ 순으로 나타나며, 구성암류는 제 4 기 충적층이 $47.02 \%$, 안산암 및 안산암질 응회암 $16.77 \%$, 유문암 및 유문암질 응회암 $13.85 \%$, 화강암 $6.73 \%$, 각섬석 화강암 $5.19 \%$, 다대포층 $4.07 \%$, 그 외 4 개 암층이 $1.13 \%$ 존 재한다. 부산도시철도 1호선은 Fig. 8에 나타난 바와 같이 비화강암 지역에 위치하므로, 타 도시에 비해 상대적으로 낮은 라돈농도를 보이고 있다.

부산도시철도 1 호선 38 개 역사 지역은 모두 신생대 제 4 기 충적층으로 대표암상은 역암, 사암 및 점토로 이루어져 있으며, 낫개역 지역은 중생대 백악기 유천층군 다대포층 으로 적색, 회색, 녹회색 사암셰일역암으로 조사되었고, 다 대포 해수욕장역 지역은 중생대 백악기 유천층군으로 안산 암류으로 조사되었다. 안산암의 경우 화산암류로 환경방사 능이 소량 나타나기 때문에 2017년 연장 개통된 1호선 다 대포 구간 6 개 역사에 비해 다대포 해수욕장역의 평균 라 돈농도가 조금 높게 나타났지만, 1 호선 전체 구간과 비교 하면 평균정도의 값으로 나타났다. 안의 연구에서 부산지 역 토양가스 내의 라돈농도는 화강암질 암석에서 약 1.09 $\mathrm{pCi}$, 안산암 $0.61 \mathrm{pCi}$, 퇴적암 $0.61 \mathrm{pCi}$ 로 조사되어 화강암 지역의 토양에서는 전반적으로 높게 나타나고, 안산암 지 역의 토양에서 상대적으로 낮게 나타난다고 보고하고 있으 므로, ${ }^{19)}$ 부산도시철도 1 호선 40 개 역사의 라돈농도는 타도 시에 비해 지반암석의 영향을 적게 받는 지역임을 알 수 있다.

\section{4. 결 론}

자연방사능 물질인 라돈은 담배연기에 이어 두 번째로 위험한 폐암유발물질로 공기보다 8 배 무거워서 지하에 거 주하는 사람에게 주의가 필요하다. 도시철도 역사 대부분 은 지하공간에 위치하고 자연환기가 어려우므로, 부산도시 철도 1 호선 40 개 역사를 대상으로 승강장 및 대합실 라돈 농도 조사를 통하여 관련 기초자료를 확보하였으며, 다음 과 같은 결과를 얻을 수 있었다.

1) 부산도시철도 1 호선 평균 라돈농도는 $8.9 \mathrm{~Bq} / \mathrm{m}^{3}$ 으로 실내공기질 권고기준 $148 \mathrm{~Bq} / \mathrm{m}^{3}$ 보다 매우 낮게 조사되
었다. 40 개 역사의 대합실 평균 라돈농도는 $8.3 \mathrm{~Bq} / \mathrm{m}^{3}$ 이었으며, 승강장의 평균 라돈농도는 $9.6 \mathrm{~Bq} / \mathrm{m}^{3}$ 으로 조 사되었다.

2) 부산도시철도 1 호선 32 개 지하역사 라돈농도는 승강장 이 $4.6 \sim 22.4 \mathrm{~Bq} / \mathrm{m}^{3}$ (평균 $10.2 \mathrm{~Bq} / \mathrm{m}^{3}$ ), 대합실이 3.4 15.4 $\mathrm{Bq} / \mathrm{m}^{3}$ (평균 $\left.8.7 \mathrm{~Bq} / \mathrm{m}^{3}\right), 8$ 개 지상역사 라돈농도는 승강장 이 $3.5 \sim 13.8 \mathrm{~Bq} / \mathrm{m}^{3}$ (평균 $7.0 \mathrm{~Bq} / \mathrm{m}^{3}$ ), 대합실이 $3.8 \sim 11.1$ $\mathrm{Bq} / \mathrm{m}^{3}$ (평균 $6.6 \mathrm{~Bq} / \mathrm{m}^{3}$ )으로 조사되었다.

3) 심도가 깊은 역사에서 상대적으로 높은 라돈농도가 조사되었다. 서대신동 승강장의 라돈농도가 48시간 평 균 $22.4 \mathrm{~Bq} / \mathrm{m}^{3}$ 으로 가장 높게 조사되었으며, 시간당 최대값은 낫개역 대합실이 $45.0 \mathrm{~Bq} / \mathrm{m}^{3}$, 동대신동 승강 장이 $44.7 \mathrm{~Bq} / \mathrm{m}^{3}$ 으로 조사되었다.

4) 지하철 운행이 중단되고 환기시설이 가동되지 않는 0 시에 서 5 시에 라돈농도가 증가하는 것으로 조사되었다. 라돈 농도 최대값의 경우 승강장은 5 시에 $14.3 \mathrm{~Bq} / \mathrm{m}^{3}$, 대합 실은 4시에 $12.5 \mathrm{~Bq} / \mathrm{m}^{3}$ 으로 나타났으며, 최소값의 경우 승강장은 20 시에 $6.6 \mathrm{~Bq} / \mathrm{m}^{3}$, 대합실은 21시에 $5.9 \mathrm{~Bq} / \mathrm{m}^{3}$ 으로 조사되었다.

5) 3 월부터 7 월까지 승강장과 대합실에서 측정한 평균 라돈농도는 온도가 낮을수록 높은 것으로 조사되었다.

6) 부산도시철도 1 호선 지역은 비화강암 지역에 위치하므 로, 라돈농도가 상대적으로 높지 않음을 알 수 있었다.

\section{References}

1. Busan Transportation Corporation Home Page, http:// www.humetro.busan.kr(2019).

2. M. Wilkening, Radon in the environment, $1^{\text {st }}$ ed., Elsevier Science, USA, pp. 137(1990).

3. Ministry of Environment, Understanding radon, a natural radioactive material in life(2016).

4. A. V. Sundal, H. Henriksen, O. Soldal, T. Strand, The influence of geological factors on indoor radon concentrations in Norway, Sci. Total Environ., 328, 41-53(2004).

5. UNSCEAR (United Nation's Scientific Committee on the Effects of Atomic Radiation), Sources and effects of ionizing radiation. Report to the general assembly with scientific annexes, UNSCEAR United Nations(2006).

6. U.S.EPA (Environmental Protection Agency), Building radon out (A step-by-step guide on How to guild radon-resistant homes, EPA, 402-K-01-002(2001).

7. Korea Environment Corporation, Indoor radon management, 50(2016).

8. J. S. Jeon, D. C. Kim, Y. W. Park, J. Y. Lee, S. S. Lee, N. J. Kim, M. Y. Kim, A study on assessment of distribution characteristics of ${ }^{222} \mathrm{Rn}$ concentration in seoul subway stations, Proceeding of the $41^{\text {st }}$ Meeting of KOSAE, pp. 552-553(2006).

9. K. T. Ha, J. Y. Kim, J. S. Jeon, D. S. Lee, D. I. Kim, M. 
Y. Kim, M. H. Kim, Characteristics of airborne radon contamination levels in seoul subway station, Report of S.I.H.E., 38, 313-318(2002).

10. J. S. Jeon, D. C. Kim, Distribution of ${ }^{222}$ Rn concentration in seoul subway stations, J. Korean Soc. Environ. Eng., 28(6), 588-595(2006).

11. J. S. Jeon, D. C. Kim, J. Y. Lee, Temporal variations and sources of ${ }^{222} \mathrm{Rn}$ in subway stations, J. Korean Soc. Environ. Eng., 29(11), 1231-1242(2007).

12. H. K. Namgung, J. H. Song, S. Y. Kim, H. M. Kim, S. B. Kwon, Characteristics of indoor air quality in the overground and underground railway stations, Journal of the Korea Academia-Industrial cooperation Society, 17(5), 17-25(2016).

13. C. M. Lee, Y. S. Kim, J. C. Kim, H. J. Jeon, Distribution of radon concentration at subway station in Seoul, J. Env. Hlth., 30(5), 469-480(2004).

14. J. S. Jeon, J. C. Yoon, H. C. Lee, S. W. Eom, Y. Z. Chae, A noticeable change in indoor radon levels after platform screen doors installation in Seoul subway station, Journal of Korean Society for Atmospheric Environment, 28(1), 59-67(2012).

15. K. N. Yu, E. C. Young, T. F. Chaj, T. Lo, R. V. Balendran, The variation of radon exhalation rates from concrete surface of different ages, Building and Environment, 31(3), 255-257(1996).

16. X. Li, B. Zheng, Y. Wang, X. Wang, A study of daily and seasonal variations of radon concentrations in underground building, J. Environmental Radioactivity, 87, 101-106(2006).

17. J. C. H. Miles, R. A. Algar, Variation in Radon-222 concentration, J. Radiol. Prot, 8(2), 103-105(1988).

18. S. A. Durrani, R. Llic, Radon measurements etched by track detectors, World Scientific, 387(1997).

19. J. K. Ahn, Distribution of radon in rock, soil, groundwater and underground space in busan, BETEC, 20-40(2007).

\section{Authors}

\section{Seongwoo Choi}

Busan Metropolitan City Institute of Health \& Environment, Korea, Researcher, ORCID (1) 0000-0002-7069-6184

\section{Youngwook Cha}

Busan Metropolitan City Institute of Health \& Environment, Korea, Researcher, ORCID (1) 0000-0002-9448-4899

\section{Youngman Cho}

Busan Metropolitan City Institute of Health \& Environment, Korea, Team manager, ORCID (1) 0000-0001-8393-0382

\section{Jeonggu Cho}

Busan Metropolitan City Institute of Health \& Environment, Korea, Department manager, ORCID () 0000-0001-7523-1274 